\title{
System $\mathrm{Cu}-\mathrm{Rh}-\mathrm{O}$ : Phase diagram and thermodynamic properties of ternary oxides $\mathrm{CuRhO}_{2}$ and $\mathrm{CuRh}_{2} \mathrm{O}_{4}$
}

\author{
K T JACOB* ${ }^{\dagger}$, T H OKABE, T UDA and Y WASEDA \\ Research Center for Metallurgical Process Engineering, Institute for Advanced Materials Processing, Tohoku \\ University, Sendai 980-8577, Japan
}

MS received 26 April 1999

\begin{abstract}
An isothermal section of the phase diagram for the system $\mathrm{Cu}-\mathrm{Rh}-\mathrm{O}$ at $1273 \mathrm{~K}$ has been established by equilibration of samples representing eighteen different compositions, and phase identification after quenching by optical and scanning electron microscopy (SEM), X-ray diffraction (XRD), and energy dispersive analysis of $\mathrm{X}$-rays (EDX). In addition to the binary oxides $\mathrm{Cu}_{2} \mathrm{O}, \mathrm{CuO}$, and $\mathrm{Rh}_{2} \mathrm{O}_{3}$, two ternary oxides $\mathrm{CuRhO}_{2}$ and $\mathrm{CuRh}_{2} \mathrm{O}_{4}$ were identified. Both the ternary oxides were in equilibrium with metallic $\mathrm{Rh}$. There was no evidence of the oxide $\mathrm{Cu}_{2} \mathrm{Rh}_{2} \mathrm{O}_{5}$ reported in the literature. Solid alloys were found to be in equilibrium with $\mathrm{Cu}_{2} \mathrm{O}$. Based on the phase relations, two solid-state cells were designed to measure the Gibbs energies of formation of the two ternary oxides. Yttria-stabilized zirconia was used as the solid electrolyte, and an equimolar mixture of $\mathrm{Rh}+\mathrm{Rh}_{2} \mathrm{O}_{3}$ as the reference electrode. The reference electrode was selected to generate a small electromotive force (emf), and thus minimize polarization of the three-phase electrode. When the driving force for oxygen transport through the solid electrolyte is small, electrochemical flux of oxygen from the high oxygen potential electrode to the low potential electrode is negligible. The measurements were conducted in the temperature range from 900 to $1300 \mathrm{~K}$. The thermodynamic data can be represented by the following equations:
\end{abstract}

$$
\begin{aligned}
& \frac{1}{2} \mathrm{Cu}_{2} \mathrm{O}+\frac{1}{2} \mathrm{Rh}_{2} \mathrm{O}_{3} \rightarrow \mathrm{CuRhO}_{2} \\
& \Delta_{\mathrm{f}(\mathrm{ox})} G^{\circ} / \mathrm{J} \mathrm{mol} \mathrm{mol}^{-1}=-18,040+0.975 \mathrm{~T} / \mathrm{K} \quad( \pm 40) \\
& \mathrm{CuO}+\mathrm{Rh}_{2} \mathrm{O}_{3} \rightarrow \mathrm{CuRh}_{2} \mathrm{O}_{4} \\
& \Delta_{\mathrm{f(ox})} G^{\circ} / \mathrm{J} \mathrm{mol}^{-1}=-23,760+1.92 \mathrm{~T} / \mathrm{K} \quad( \pm 325),
\end{aligned}
$$

where $\Delta_{\mathrm{f}(\mathrm{ox})} G^{0}$ is the standard Gibbs energy of formation of the interoxide compounds from their component binary oxides. Based on the thermodynamic information, chemical potential diagrams for the system $\mathrm{Cu}-\mathrm{Rh}-\mathrm{O}$ were developed.

Keywords. Phase equilibria; ternary $\mathrm{Cu}-\mathrm{Rh}-\mathrm{O}$; Gibbs energy of formation; enthalpy of formation; entropy of formation; chemical potential diagram.

\section{Introduction}

As a part of systematic studies on phase equilibria and thermodynamic properties of compounds in the ternary systems $\mathrm{Cu}-\mathrm{X}-\mathrm{O}$ (Jacob and Alcock 1975, 1976; Jacob et al 1977, 1986, 1992a, b, 1993a, b; Kale and Jacob 1989; Jacob and Mathews 1992; Mathews and Jacob 1993a, b, 1994; Mathews et al 1993), measurements have been made on the $\mathrm{Cu}-\mathrm{Rh}-\mathrm{O}$ system. The ternary oxides containing copper and rhodium have potential application in

\footnotetext{
*Author for correspondence

${ }^{\dagger}$ On scholastic leave from the Department of Metallurgy, Indian Institute of Science, Bangalore 560012 , India.
}

catalysis and electrochemistry. Thermodynamic information on these compounds is useful for assessing their stability in different environments and interactions with support materials. The information is also important for the design of processes for the recovery of rhodium from scrap. Phase diagrams of higher order systems containing these elements can be readily computed from thermodynamic data on ternary compounds.

Three stable ternary compounds $\left(\mathrm{CuRhO}_{2}, \mathrm{CuRh}_{2} \mathrm{O}_{4}\right.$ and $\mathrm{Cu}_{2} \mathrm{Rh}_{2} \mathrm{O}_{5}$ ) have been reported in the system $\mathrm{Cu}-\mathrm{Rh}-\mathrm{O}$. The compound $\mathrm{CuRhO}_{2}$ has delafossite $\left(\mathrm{CuFeO}_{2}\right)$ type structure, belonging to the rhombohedral system, space group $R \overline{3} m$ (166), with $a=0.3074 \mathrm{~nm}$ and $c=1.7092 \mathrm{~nm}$ (Neininger et al 1990). At room tempe- 
rature, the compound $\mathrm{CuRh}_{2} \mathrm{O}_{4}$ has a tetragonally distorted spinel structure (Bertaut et al 1959), space group I4 1 /amd (141), with $a=0.6175 \mathrm{~nm}$ and $c=0.7902 \mathrm{~nm}$ (Schulz and Eysel 1990). At temperatures above $850 \mathrm{~K}$, the tetragonal distortion disappears and $\mathrm{CuRh}_{2} \mathrm{O}_{4}$ has the cubic spinel structure (Blasse 1963). The dissociation pressures of $\mathrm{CuRhO}_{2}$ and $\mathrm{CuRh}_{2} \mathrm{O}_{4}$ were measured by a manometric technique (Schmahl and Minzl 1965). The compound $\mathrm{Cu}_{2} \mathrm{Rh}_{2} \mathrm{O}_{5}$ with tetragonal symmetry, with $a=0.4901 \mathrm{~nm}$ and $c=1.556 \mathrm{~nm}$, was reported along the pseudo-binary $\mathrm{CuO}-\mathrm{Rh}_{2} \mathrm{O}_{3}$ (Kahan et al 1987). It is said to decompose in air to $\mathrm{Cu}_{2} \mathrm{O}, \mathrm{Rh}$ and $\mathrm{O}_{2}$ at $1403( \pm 10) \mathrm{K}$. Thermodynamic properties of solid $\mathrm{Cu}-\mathrm{Rh}$ alloys have been measured recently (Priya and Jacob 1999). The alloys are characterized by strong positive deviations from ideality. The excess Gibbs energy of mixing can be represented by the equation:

$$
\begin{gathered}
\Delta G^{\mathrm{E}} / \mathrm{J} \mathrm{mol}^{-1}=X_{\mathrm{Rh}}\left(1-X_{\mathrm{Rh}}\right) \times \\
\left\{(54,000-20 \cdot 187 T / \mathrm{K}) X_{\mathrm{Rh}}+\right. \\
\left.(41,330-15 \cdot 45 T / \mathrm{K})\left(1-X_{\mathrm{Rh}}\right)\right\} .
\end{gathered}
$$

The solid state miscibility gap is characterized by an upper critical temperature of $1208 \mathrm{~K}$ and critical composition $X_{\mathrm{Rh}}=0.59$.

In this study, phase equilibria in the system $\mathrm{Cu}-\mathrm{Rh}-\mathrm{O}$ were first determined at $1408 \mathrm{~K}$ by isothermal equilibration and phase analysis of quenched samples. Based on the phase diagram, solid-state cells were designed to measure the Gibbs energies of formation of the ternary oxides. In general, the electrochemical method has been found simpler and superior to other techniques for the determination of Gibbs energy of formation of oxides (Pratt 1990). Yttria-stabilized zirconia (YSZ) was used as the solid electrolyte. The reference electrode was chosen so that the cell emf was less than $100 \mathrm{mV}$. Polarization of the working electrode is minimized by reducing the driving force for electrochemical transport of oxygen through the solid electrolyte.

\section{Experimental}

\subsection{Materials}

Fine powders of $\mathrm{Cu}, \mathrm{Rh}, \mathrm{Cu}_{2} \mathrm{O}, \mathrm{CuO}$ and $\mathrm{Rh}_{2} \mathrm{O}_{3}$ used in this study were of $99.99 \%$ purity. The $\mathrm{Rh}_{2} \mathrm{O}_{3}$ powder was heated at $1250 \mathrm{~K}$ under dry oxygen gas for -3 days. $\mathrm{X}$ ray diffraction analysis of the sample after annealing, indicated that the oxide had an orthorhombic structure, space group Pbca (61), with $a=0.5148, b=0.5438$ and $c=1.4693 \mathrm{~nm}$. An intimate equimolar mixture of $\mathrm{Cu}_{2} \mathrm{O}$ and $\mathrm{Rh}_{2} \mathrm{O}_{3}$ heated in evacuated quartz ample at $1250 \mathrm{~K}$ for 5 days produced the black inter-oxide compound $\mathrm{CuRhO}_{2}$. The compound $\mathrm{CuRh}_{2} \mathrm{O}_{4}$ having light brown colour was obtained by annealing a stoichiometric mixture of $\mathrm{CuO}$ and $\mathrm{Rh}_{2} \mathrm{O}_{3}$ at $1325 \mathrm{~K}$ for 12 days. In each case the sample was cooled to room temperature, ground to -325 mesh, and repelletized at $150 \mathrm{MPa}$ using a steel die for further heat treatment at intervals of two days. Attempts to synthesize $\mathrm{Cu}_{2} \mathrm{Rh}_{2} \mathrm{O}_{5}$ were unsuccessful. A close examination of the XRD pattern for $\mathrm{Cu}_{2} \mathrm{Rh}_{2} \mathrm{O}_{5}$ given in the literature (Kahan et al 1987) indicated that it closely resembles that of a mixture of $\mathrm{CuO}$ and $\mathrm{CuRh}_{2} \mathrm{O}_{4}$. The alloy buttons were prepared by vacuum arc melting on a water-cooled copper hearth. Each button was remelted three times to ensure chemical homogeneity of the alloy. The formation of alloys and interoxide compounds was confirmed by XRD.

\subsection{Determination of the phase diagram}

The phase relations were explored by equilibrating mixtures of metals and alloys with the different oxides at $1273 \mathrm{~K}$, followed by quenching in liquid nitrogen or chilled mercury and phase identification. Thus, eighteen compositions inside the ternary were equilibrated for periods up to 12 days. During this period, twice the samples were quenched, ground to -325 mesh, and repelletized for further heat treatment. The phase compositions of the samples were unaltered by further heating. The overall composition of the samples studied is shown on the Gibbs triangle in figure 1.

Two arrangements were used for equilibrating samples at high temperature. Several mixtures containing $\mathrm{CuO}$, $\mathrm{Rh}_{2} \mathrm{O}_{3}, \mathrm{CuRhO}_{2}$ and $\mathrm{CuRh}_{2} \mathrm{O}_{4}$ were equilibrated in pure oxygen at a pressure of $0.1 \mathrm{MPa}$, using an apparatus described earlier (Jacob and Mathews 1991). The samples were held in alumina crucibles, and kept on sacrificial

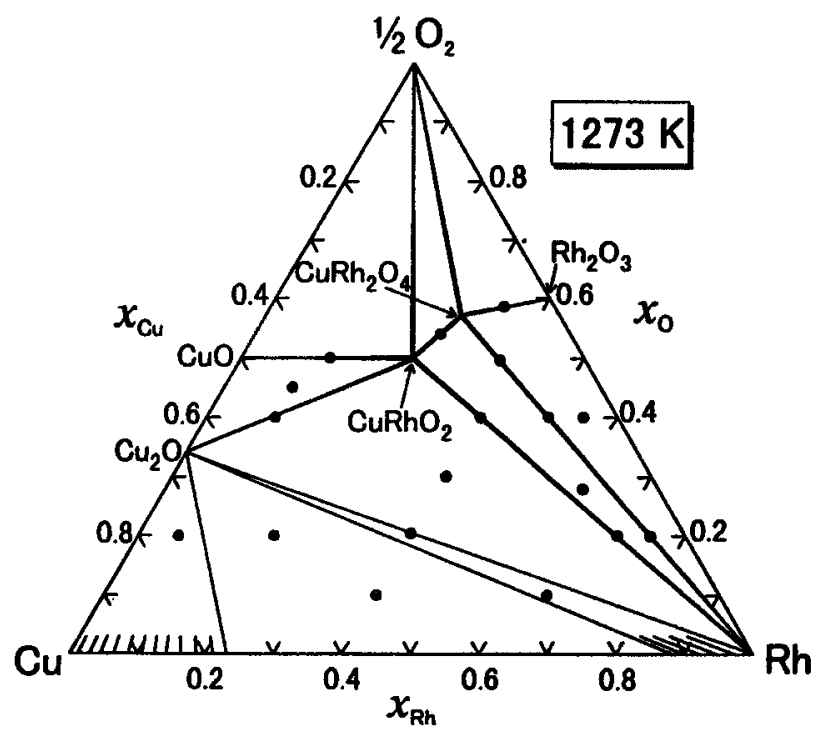

Figure 1. Isothermal section of the phase diagram for the system $\mathrm{Cu}-\mathrm{Rh}-\mathrm{O}$ at $1273 \mathrm{~K}$. The average composition of the samples examined in this study is shown by the symbol $\oplus$. 
disks of the same composition. The mass of each sample pellet was determined before and after equilibration. The change in mass was used as an indicator of oxidation or reduction. Sample pellets containing either pure metal or alloy were contained in closed alumina crucibles, which were sealed in evacuated quartz ampoules. In many cases, samples of the same overall composition were made, using different starting materials. Optical and scanning electron microscopy, EDX, and XRD identified phases present in quenched samples.

\subsection{Measurement of Gibbs energies of formation of ternary oxides}

The reversible emf of the following solid-state cells were measured as a function of temperature:

$$
\begin{aligned}
& \mathrm{Pt}-\mathrm{Rh}, \mathrm{CuRhO}_{2}+\mathrm{CuRh}_{2} \mathrm{O}_{4}+\mathrm{Rh} / /\left(\mathrm{Y}_{2} \mathrm{O}_{3}\right) \mathrm{ZrO}_{2} / / \\
& \mathrm{Rh}+\mathrm{Rh}_{2} \mathrm{O}_{3}, \mathrm{Pt}-\mathrm{Rh} \quad(\mathrm{Cell} \mathrm{I}) \\
& \mathrm{Pt}-\mathrm{Rh}, \mathrm{CuRhO}_{2}+\mathrm{Cu}_{2} \mathrm{O}+\mathrm{Rh} / /\left(\mathrm{Y}_{2} \mathrm{O}_{3}\right) \mathrm{ZrO}_{2} / / \\
& \mathrm{Rh}+\mathrm{Rh}_{2} \mathrm{O}_{3}, \mathrm{Pt}-\mathrm{Rh} \quad(\mathrm{Cell} \mathrm{II})
\end{aligned}
$$

Both cells are written such that the right hand electrodes are positive. A yttria-stabilized zirconia tube was used as the solid electrolyte and a mixture of $\mathrm{Rh}+\mathrm{Rh}_{2} \mathrm{O}_{3}$ in the molar ratio $1: 1.5$ as the reference electrode. $\left(\mathrm{Y}_{2} \mathrm{O}_{3}\right) \mathrm{ZrO}_{2}$ is an oxygen ion conductor with ionic transport number $>0.99$ at the temperatures and oxygen partial pressures encountered in this study. The tube was leak tested and found impervious. A schematic diagram of the apparatus used in this study is shown in figure 2 . The reference electrodes were contained inside the zirconia tube. In the cells used in this study, the partial pressure of oxygen at the reference and working electrode was quite appreciable, especially at the higher temperatures. Therefore, the static sealed design used by Charette and Flengas (1968) was found more appropriate than other designs that employ either dynamic vacuum or inert gas flow over the electrodes (Pratt 1990; Kale and Jacob 1992).

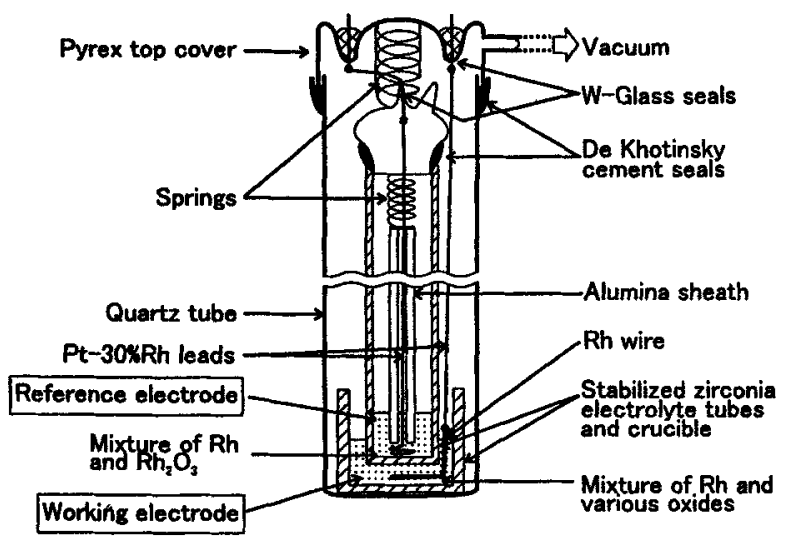

Figure 2. A schematic diagram of the apparatus used for hightemperature emf measurements.
A mixture of $\mathrm{Rh}+\mathrm{Rh}_{2} \mathrm{O}_{3}$ in the molar ratio $1: 1.5$ was rammed against the closed end of a stabilized zirconia tube with a Pt-30\% Rh wire embedded in the mixture. An alumina sheath was used to insulate the metallic lead and to press the reference electrode against the flat end of the zirconia tube. The top of the zirconia tube was closed with a tight-fitting bell-shaped Pyrex tube, which supported a tungsten electrode connection sealed into the glass. The joint between the bell and the zirconia tube was sealed with De Khotinsky cement. A spring placed between the bell and the alumina sheath applied pressure on the reference electrode. The assembled reference electrode half-cell was first evacuated using a side arm tube shown in the diagram, then heated to $\sim 600 \mathrm{~K}$, and finally the tube was flame sealed under vacuum.

The working electrode consisted of an intimate mixture of $\mathrm{CuRhO}_{2}+\mathrm{CuRh}_{2} \mathrm{O}_{4}+\mathrm{Rh}$ in the molar ratio $1: 1.5: 1$ in cell $\mathrm{I}$, and $\mathrm{CuRhO}_{2}+\mathrm{Cu}_{2} \mathrm{O}+\mathrm{Rh}$ in the ratio $1: 1 \cdot 5: 1$ in cell II. In each case, an excess of the component that decomposed to establish the oxygen pressure in the closed system was taken. The working electrode was prepared by consolidating an intimate mixture of constituent phases in a stabilized-zirconia crucible, with a Pt-30\%Rh wire embedded in the powder. The reference half-cell assembly rested on the working electrode contained in a zirconia crucible.

The cell was assembled inside a fused quartz enclosure as shown in the figure. The reference electrode assembly was pressed down by means of a second metal spring placed between the bell and the top Pyrex cover. The top cover supported two tungsten-glass seals through which electrical connections were made. All electrode connections were silver-soldered. Finally, the top cover was cemented in place by melting the De Khotinsky cement in the ring container shown in the diagram. The cement was allowed to solidify while pressing the top cover against the spring. Then the outer quartz enclosure was also evacuated from a side arm tube and flame sealed under vacuum.

The entire assembly shown in figure 2 was placed inside a vertical resistance furnace, with the electrodes located in the even-temperature zone $( \pm 1 \mathrm{~K})$. The oxygen partial pressure in the evacuated and sealed enclosures around the working and reference electrodes was established by the dissociation of the oxides. The upper part of the assembly, where cement seals were located, remained at room temperature during measurement. A Faraday cage made from Kanthal tape was placed between the furnace and the cell assembly. The foil was grounded to minimize induced emf on cell leads. The temperature of the furnace was controlled to $\pm 1 \mathrm{~K}$. The temperature was measured by a Pt/Pt-13\%Rh thermocouple, checked against the melting point of gold. The cell potentials were measured with a high-impedance digital voltmeter with a sensitivity of $\pm 0.01 \mathrm{mV}$. The potential readings were corrected for small thermal emfs, measured 
separately using a symmetric cell with identical electrodes. At the end of each experiment, the electrodes were cooled to room temperature and examined by optical and scanning electron microscopy and XRD. Only small changes in the relative concentration of the constituents were observed, the number and nature of the phases remained unaltered. The change in relative concentration was consistent with the expected decomposition of one of the oxides at high temperature to generate the equilibrium oxygen pressures in sections of the apparatus.

\section{Results and discussion}

\subsection{Phase diagram}

The isothermal section of equilibrium phase diagram for the system $\mathrm{Cu}-\mathrm{Rh}-\mathrm{O}$ at $1273 \mathrm{~K}$, composed from the results obtained by isothermal equilibration and phase identification of quenched samples by optical and scanning electron microscopy, EDX and XRD, is shown in figure 1. Equilibrium was assumed when the XRD or EDX showed no change after successive heat treatments. In several phase fields, equilibrium was confirmed by using different starting materials to produce samples of the same average chemical composition, and verifying that the samples had identical phase-composition after equilibration. Along the $\mathrm{Cu}-\mathrm{Rh}$ binary, there is a miscibility gap separating the terminal solid solutions. The range of immiscibility at $1273 \mathrm{~K}$ is $0.232<X_{\mathrm{Rh}}$ $<0.883$. This is larger than that given in the ASM phase diagram compilation, $0.330<X_{\mathrm{Rh}}<0.825$ (Massalski et al 1990). The $\mathrm{Cu}-\mathrm{Rh}$ solid alloys were found to be in equilibrium with $\mathrm{Cu}_{2} \mathrm{O}$.

The stability of two ternary oxides, $\mathrm{CuRhO}_{2}$ and $\mathrm{CuRh}_{2} \mathrm{O}_{4}$, reported in the literature (Neininger et al 1990; Schulz and Eysel 1990) was confirmed. The ternary compounds are slightly nonstoichiometric, although their precise boundaries could not be established using EDX. The XRD patterns of the oxides in different phase fields were almost identical. The valence of $\mathrm{Rh}$ in all the oxides encountered in this study was three. The compound $\mathrm{CuRh}_{2} \mathrm{O}_{4}$ coexists with $\mathrm{Rh}_{2} \mathrm{O}_{3}$, but not with oxides of copper. The reverse is true for $\mathrm{CuRhO}_{2}$, which is in equilibrium with both $\mathrm{Cu}_{2} \mathrm{O}$ and $\mathrm{CuO}$, but not $\mathrm{Rh}_{2} \mathrm{O}_{3}$. The third inter-oxide compound $\mathrm{Cu}_{2} \mathrm{Rh}_{2} \mathrm{O}_{5}\left(2 \mathrm{CuO} \cdot \mathrm{Rh}_{2} \mathrm{O}_{3}\right)$ reported in the literature (Kahan et al 1987) could not be identified in this study. The XRD pattern of a two-phase mixture of $\mathrm{CuO}$ and $\mathrm{CuRh}_{2} \mathrm{O}_{4}$ obtained in this study resembled closely the pattern for $\mathrm{Cu}_{2} \mathrm{Rh}_{2} \mathrm{O}_{5}$ reported by Kahan et al (1987). The present result leads to the conclusion that $\mathrm{Cu}_{2} \mathrm{Rh}_{2} \mathrm{O}_{5}$ is unstable at $1273 \mathrm{~K}$. In all the phase fields the orthorhombic form of $\mathrm{Rh}_{2} \mathrm{O}_{3}$ was present.

Metal $\mathrm{Rh}$ was found to be in equilibrium with all the oxides except CuO. Three three-phase fields involving $R h$ and the various oxides were identified: (i) $\mathrm{Rh}+\mathrm{Rh}_{2} \mathrm{O}_{3}+\mathrm{CuRh}_{2} \mathrm{O}_{4}$, (ii) $\mathrm{Rh}+\mathrm{CuRh}_{2} \mathrm{O}_{4}+\mathrm{CuRhO}_{2}$, and (iii) $\mathrm{Rh}+\mathrm{CuRhO}_{2}+\mathrm{Cu}_{2} \mathrm{O}$. Each of these phase-fields involving three condensed phases, is characterized by unique oxygen potential at constant temperature and total pressure in accordance with the phase rule. The chemical potential of oxygen for the three-phase field involving $R h$, $\mathrm{Rh}_{2} \mathrm{O}_{3}$ and $\mathrm{CuRh}_{2} \mathrm{O}_{4}$ is determined by the equilibrium involving the two phases $\mathrm{Rh}$ and $\mathrm{Rh}_{2} \mathrm{O}_{3} ; \mathrm{CuRh}_{2} \mathrm{O}_{4}$ is present as an inert component. The oxygen partial pressure over the other two three-phase fields is established by the dissociation of the less stable oxide (or the oxide with higher oxygen to metal ratio) to yield the other two condensed phases and oxygen gas at reduced pressure. Measurement of the oxygen partial pressure in the threephase regions provides a means for determining the Gibbs energy of formation of the ternary oxides. The oxygen potential of the three-phase field involving $\mathrm{Cu}_{2} \mathrm{O}, \mathrm{CuO}$ and $\mathrm{CuRhO}_{2}$ is identical to that for $\mathrm{Cu}_{2} \mathrm{O}-\mathrm{CuO}$ equilibrium since solid solubility between these oxides is negligible.

All the oxide phases except $\mathrm{Cu}_{2} \mathrm{O}$ are stable in the presence of pure oxygen gas at $1273 \mathrm{~K}$. The stability of cuprous rhodite $\left(\mathrm{CuRhO}_{2}\right)$ in pure oxygen is unexpected. Normally, one would expect to see oxides with copper in divalent state in equilibrium with pure oxygen gas. Thus, $\mathrm{Rh}_{2} \mathrm{O}_{3}$ appears to stabilize $\mathrm{Cu}(\mathrm{I})$ in the ternary oxides more than $\mathrm{Cu}(\mathrm{II})$.

\subsection{Gibbs energies of formation of ternary oxides}

The reversible emfs of cells I and II are shown as a function of temperature in figures 3 and 4, respectively. The reversibility of the emf was established by microcoulometric titration in both directions. A small current $(\sim 50 \mu \mathrm{A})$ was passed through the cell using an external potential source for $-5 \mathrm{~min}$, and the open circuit emf was subsequently monitored as a function of time. The emf was found to return to the same value before each titration. The chemical potential of oxygen at each electrode was displaced from equilibrium by an essentially infinitesimal amount during each titration. Since the electrodes returned to the same potential after such displacements in opposite directions, attainment of equilibrium at each electrode was demonstrated. The linear least-squares regression analysis of the emf of cells I and II gives,

$$
\begin{aligned}
& E_{\mathrm{I}} / \mathrm{mV}=12.66-2.33 \times 10^{-3} \mathrm{~T} / \mathrm{K}( \pm 0.05), \\
& E_{\mathrm{II}} / \mathrm{mV}=62.32-3.37 \times 10^{-3} \mathrm{~T} / \mathrm{K}( \pm 0.13),
\end{aligned}
$$

where the uncertainty limits correspond to twice the standard error estimate $(2 \sigma)$. The emf of cell I is related to the standard Gibbs energy change for the reaction:

$$
\frac{2}{3} \mathrm{Rh}_{2} \mathrm{O}_{3}+\mathrm{CuRhO}_{2} \rightarrow \frac{1}{3} \mathrm{Rh}+\mathrm{CuRh}_{2} \mathrm{O}_{4}
$$




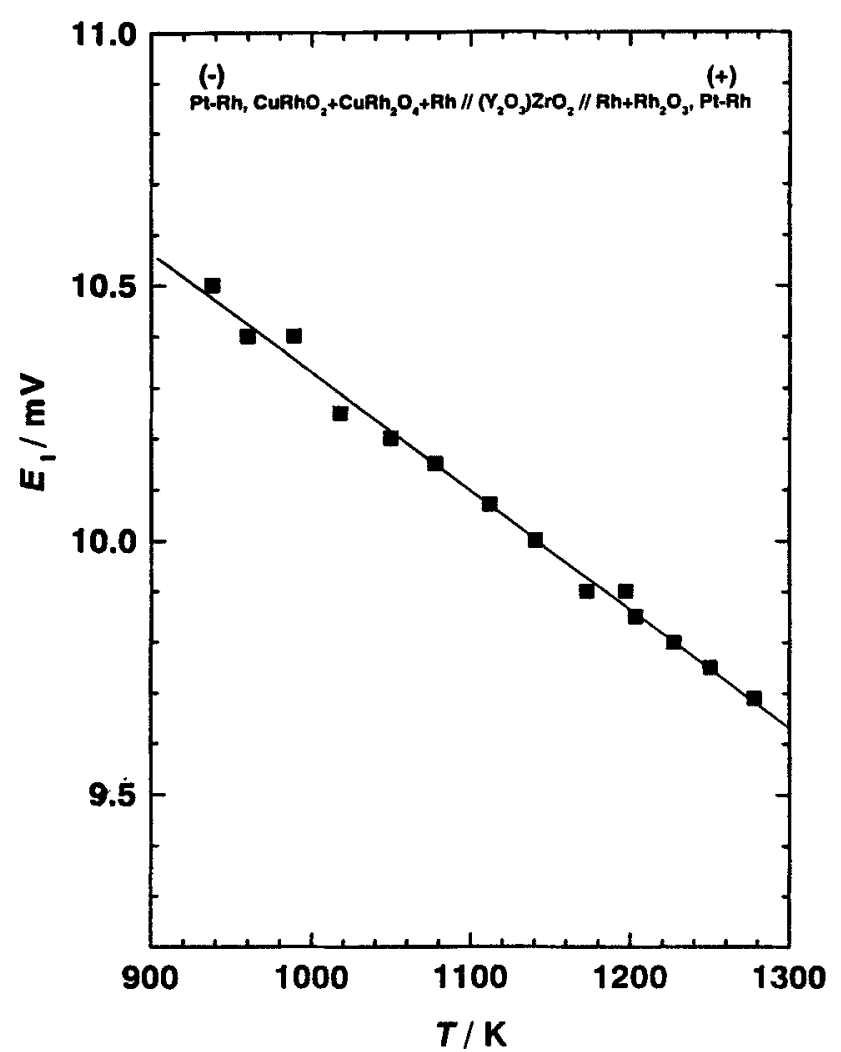

Figure 3. Variation of the reversible emf of cell I as a function of temperature.

$$
\begin{aligned}
\Delta_{\mathrm{r}(4)} G^{\circ} / \mathrm{J} \mathrm{mol} & =-4 \mathrm{~F} E_{\mathrm{I}} \\
& =-4,886+0.90 \mathrm{~T} / \mathrm{K}( \pm 20),
\end{aligned}
$$

where $\mathrm{F}$ is the Faraday constant and $\Delta_{\mathrm{r}(4)} G^{\circ}$ represents the standard Gibbs energy change for reaction (4). The emf of cell II is related to the standard Gibbs energy of formation of $\mathrm{CuRhO}_{2}$ from its component oxides $\mathrm{Cu}_{2} \mathrm{O}$ and $\mathrm{Rh}_{2} \mathrm{O}_{3}$ $\left(\Delta_{\mathrm{f}(\mathrm{ox})} G\right)$ according to the reaction:

$$
\begin{aligned}
& \mathrm{Cu}_{2} \mathrm{O}+\mathrm{Rh}_{2} \mathrm{O}_{3} \text { (ortho) } \rightarrow 2 \mathrm{CuRhO}_{2}, \\
& \begin{aligned}
\Delta_{\mathrm{r}(6)} G^{\circ} / \mathrm{J} \mathrm{mol}^{-1} & =2 \Delta_{\mathrm{f}(\mathrm{ox})} G^{\circ}\left(\mathrm{CuRhO}_{2}\right) / \mathrm{J} \mathrm{mol}^{-1} \\
& =-36,078+1.95 \mathrm{~T} / \mathrm{K} \quad( \pm 80) .
\end{aligned}
\end{aligned}
$$

Recently, the Gibbs energy of formation of $\mathrm{Rh}_{2} \mathrm{O}_{3}$ with orthorhombic structure has been measured accurately (Jacob and Sriram 1994). The results in the temperature range from 875 to $1325 \mathrm{~K}$ can be represented by the relation,

$$
\begin{aligned}
& 2 \mathrm{Rh}+\frac{3}{2} \mathrm{O}_{2} \rightarrow \mathrm{Rh}_{2} \mathrm{O}_{3} \text { (ortho), } \\
& \Delta_{\mathrm{f}} G^{\circ}\left(\mathrm{Rh}_{2} \mathrm{O}_{3}\right) / \mathrm{J} \mathrm{mol}{ }^{-1} \\
& =-396,365+282.00 \mathrm{~T} / \mathrm{K} \quad( \pm 120) .
\end{aligned}
$$

The thermodynamic properties of $\mathrm{Cu}_{2} \mathrm{O}$ and $\mathrm{CuO}$ are well established. For the formation of $\mathrm{Cu}_{2} \mathrm{O}$ from solid $\mathrm{Cu}$ and

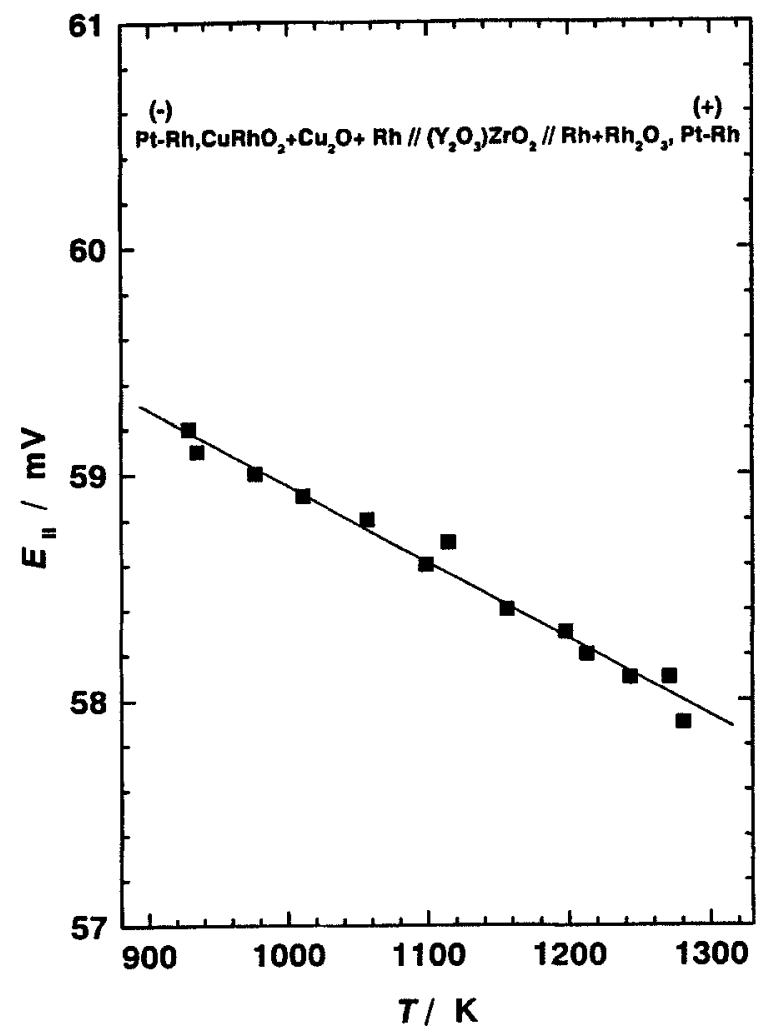

Figure 4. Temperature dependence of the reversible emf of cell II.

$\mathrm{O}_{2}$ (Jacob and Jeffes 1971),

$$
\begin{aligned}
& 2 \mathrm{Cu}+\frac{1}{2} \mathrm{O}_{2} \rightarrow \mathrm{Cu}_{2} \mathrm{O}, \\
& \Delta_{\mathrm{f}} G^{\circ}\left(\mathrm{Cu}_{2} \mathrm{O}\right) / \mathrm{J} \mathrm{mol}{ }^{-1} \\
& =-167,690+71.60 \mathrm{~T} / \mathrm{K} \quad( \pm 420) .
\end{aligned}
$$

For the formation of $\mathrm{CuO}$ from $\mathrm{Cu}_{2} \mathrm{O}$ and $\mathrm{O}_{2}$ (Jacob and Alcock 1975);

$$
\begin{aligned}
& \frac{1}{2} \mathrm{Cu}_{2} \mathrm{O}+\frac{1}{4} \mathrm{O}_{2} \rightarrow \mathrm{CuO}, \\
& \Delta_{\mathrm{r}(12)} G^{\circ} / \mathrm{J} \mathrm{mol}{ }^{-1} \\
& =-65,220+46.95 \mathrm{~T} / \mathrm{K} \quad( \pm 320) .
\end{aligned}
$$

Combining reactions (4), (6), (8) and (12), one obtains the reaction representing the formation of $\mathrm{CuRh}_{2} \mathrm{O}_{4}$ from its component oxides:

$$
\begin{aligned}
& \mathrm{CuO}+\mathrm{Rh}_{2} \mathrm{O}_{3} \text { (ortho) } \rightarrow \mathrm{CuRh}_{2} \mathrm{O}_{4} \\
& \begin{aligned}
\Delta_{\mathrm{r}(14)} G^{\circ} / \mathrm{J} \mathrm{mol} l^{-1} & =\Delta_{\mathrm{f}(\mathrm{ox})} G^{\circ}\left(\mathrm{CuRh}_{2} \mathrm{O}_{4}\right) / \mathrm{J} \mathrm{mol}^{-1} \\
& =-23,765+1.925 \mathrm{~T} / \mathrm{K}( \pm 325) .
\end{aligned}
\end{aligned}
$$

The oxygen chemical potential $\left(\Delta \mu_{\mathrm{O}_{2}}=R T \ln P_{\mathrm{O}_{2}}\right)$ associated with the three-phase fields $\mathrm{Rh}+\mathrm{CuRhO}_{2}+\mathrm{CuRh}_{2} \mathrm{O}_{4}$ and $\mathrm{Rh}+\mathrm{Cu}_{2} \mathrm{O}+\mathrm{CuRhO}_{2}$ can be obtained from the emfs of cells I and II along with information on the oxygen 
potential of the reference electrode $\mathrm{Rh}+\mathrm{Rh}_{2} \mathrm{O}_{3}$ (9). For oxygen potential defined by the reaction,

$$
\begin{aligned}
& \mathrm{CuRhO}_{2}+\mathrm{Rh}+\mathrm{O}_{2} \rightarrow \mathrm{CuRh}_{2} \mathrm{O}_{4}, \\
& \Delta_{\mathrm{r}(16)} G^{\circ} / \mathrm{J} \mathrm{mol}{ }^{-1} \\
& =\Delta \mu_{\mathrm{O}_{2}}\left(\mathrm{Rh}+\mathrm{CuRhO}_{2}+\mathrm{CuRh}_{2} \mathrm{O}_{4}\right) / \mathrm{J} \mathrm{mol}^{-1} \\
& =-269,130+188.90 \mathrm{~T} / \mathrm{K} \quad( \pm 85) .
\end{aligned}
$$

The oxygen potential defined by the reaction,

$$
\begin{aligned}
& \frac{2}{3} \mathrm{Cu}_{2} \mathrm{O}+\frac{4}{3} \mathrm{Rh}+\mathrm{O}_{2} \rightarrow \frac{4}{3} \mathrm{CuRhO}_{2}, \\
& \Delta_{\mathrm{r}(18)} G^{\circ} / \mathrm{J} \mathrm{mol}{ }^{-1} \\
= & \Delta \mu_{\mathrm{O}_{2}}\left(\mathrm{Rh}+\mathrm{Cu}_{2} \mathrm{O}+\mathrm{CuRhO}_{2}\right) / \mathrm{J} \mathrm{mol}^{-1} \\
= & -288,295+189.30 \mathrm{~T} / \mathrm{K} \quad( \pm 95) .
\end{aligned}
$$

The values for the oxygen partial pressure corresponding to the dissociation of $\mathrm{CuRhO}_{2}$ and $\mathrm{CuRh}_{2} \mathrm{O}_{4}$ computed from (17) and (18) are compared with the direct pressure measurements of Schmahl and Minzl (1965) in figure 5. There is good agreement between the two sets of data. The dissociation temperatures of the oxides in air are compared in table 1. More accurate values of the enthalpy and entropy of formation of $\mathrm{CuRhO}_{2}$ and $\mathrm{CuRh}_{2} \mathrm{O}_{4}$ can be obtained from the results of this study because the measurements have been conducted over a larger temperature range.

It is interesting to compute the standard Gibbs energy change for the reaction

$$
4 \mathrm{CuRhO}_{2}+\mathrm{O}_{2} \rightarrow 2 \mathrm{CuRh}_{2} \mathrm{O}_{4}+2 \mathrm{CuO}
$$

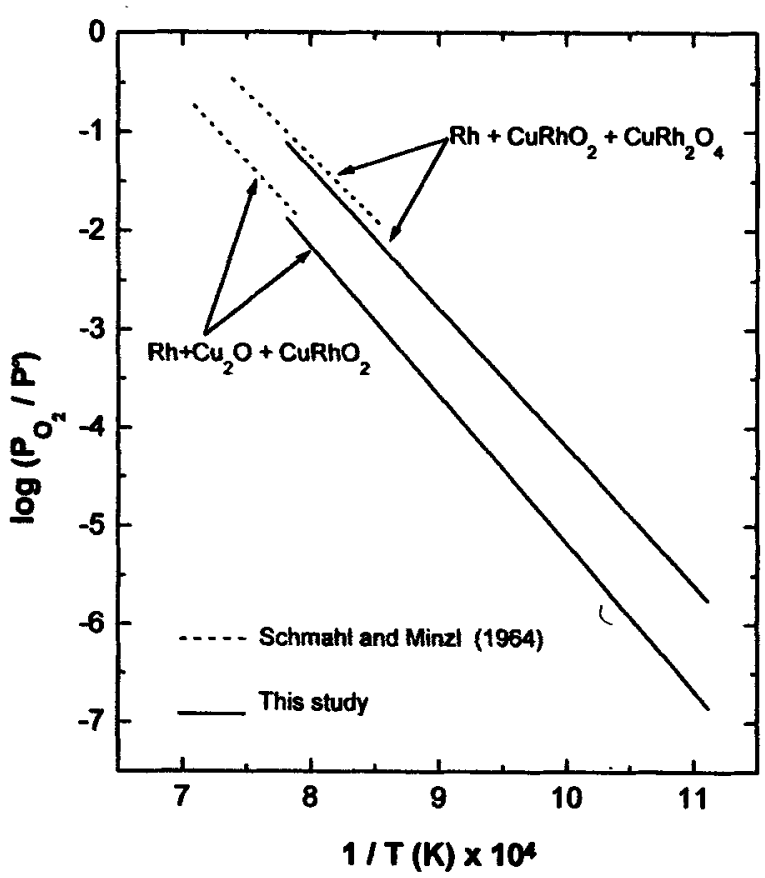

Figure 5. Comparison of the oxygen chemical potentials for three-phase equilibria measured in this study with values reported in the literature. from data obtained in this study:

$$
\begin{aligned}
& \Delta_{\mathrm{r}(20)} G^{\circ} / \mathrm{J} \mathrm{mol} \\
& \quad=-236,255+187.76 \mathrm{~T} / \mathrm{K} \quad( \pm 680) .
\end{aligned}
$$

The standard free energy change for reaction (20) becomes zero at $1258( \pm 4) \mathrm{K}$. Thus, below $1258 \mathrm{~K}$ $\mathrm{CuRhO}_{2}$ is unstable in pure oxygen at a pressure of $0 \cdot 1 \mathrm{MPa}$. The phase diagram at $T<1258( \pm 4) \mathrm{K}$ should have a tie line connecting $\mathrm{CuO}$ and $\mathrm{CuRh}_{2} \mathrm{O}_{4}$, in place of the tie line connecting $\mathrm{CuRhO}_{2}$ and $\mathrm{O}_{2}$. At $T>1258( \pm 4) \mathrm{K}$, reaction (20) can proceed at oxygen pressures greater than $0.1 \mathrm{MPa}$. In air at ambient pressure the tie line switch would occur at $1176( \pm 4) \mathrm{K}$.

The Gibbs energy of formation of the ternary oxides from elements can be readily calculated using values for the Gibbs energy of formation of $\mathrm{Rh}_{2} \mathrm{O}_{3}, \mathrm{Cu}_{2} \mathrm{O}$ and $\mathrm{CuO}$

\begin{tabular}{|c|c|c|}
\hline Compound & $\begin{array}{l}\Delta G_{\mathrm{i}}^{\circ} / \mathrm{J} \mathrm{mol}{ }^{-1} \\
(900-1300 \mathrm{~K})\end{array}$ & Reference \\
\hline $\mathrm{Cu}_{2} \mathrm{O}$ & $\begin{array}{c}-167,690+71.60 T / K \\
( \pm 420)\end{array}$ & Jacob and Jeffes (1971) \\
\hline $\mathrm{CuO}$ & $\begin{array}{c}-149,070+82.75 T / K \\
( \pm 240)\end{array}$ & Jacob and Alcock (1976) \\
\hline $\begin{array}{l}\mathrm{Rh}_{2} \mathrm{O}_{3} \\
\text { (ortho) }\end{array}$ & $\begin{array}{c}-396,365+282.00 T / K \\
( \pm 120)\end{array}$ & Jacob and Sriram (1994) \\
\hline $\mathrm{CuRh}_{2} \mathrm{O}_{4}$ & $\begin{array}{c}-569,200+366.67 T / K \\
( \pm 550)\end{array}$ & This study \\
\hline $\mathrm{CuRhO}_{2}$ & $\begin{array}{c}-300,070+177.78 \mathrm{~T} / \mathrm{K} \\
( \pm 225)\end{array}$ & This study \\
\hline
\end{tabular}
$(9,11$ and 13). The calculated values are given in table 2 . Using the Neumann-Kopp rule to estimate the heat capacity of the ternary oxides relative to their binary oxides, thermodynamic properties of the double oxides at $298.15 \mathrm{~K}$ can be evaluated. The standard enthalpies and

Table 1. Dissociation temperatures of $\mathrm{Rh}_{2} \mathrm{O}_{3}, \mathrm{CuRh}_{2} \mathrm{O}_{4}$ and $\mathrm{CuRhO}_{2}$ in air.

\begin{tabular}{lcl}
\hline Compound & $\begin{array}{c}\text { Dissociation } \\
\text { temperature } \\
(T / K)\end{array}$ & \multicolumn{1}{c}{ Reference } \\
\hline $\mathrm{Rh}_{2} \mathrm{O}_{3}$ & $1305( \pm 5)$ & $\begin{array}{l}\text { Schmahl and Minzl (1965) } \\
\text { Jacob and Sriram (1994) }\end{array}$ \\
& $1315( \pm 2)$ & Schmahl and Minzl (1965) \\
$\mathrm{CuRh}_{2} \mathrm{O}_{4}$ & $1323( \pm 5)$ & $\begin{array}{l}\text { This study } \\
\end{array}$ \\
$\mathrm{CuRhO}_{2}$ & $1333( \pm 3)$ & Schmahl and Minzl (1965) \\
& $1418( \pm 5)$ & \begin{tabular}{l} 
This study \\
\hline
\end{tabular} \\
\hline
\end{tabular}

Table 2. The standard Gibbs energies of formation of $\mathrm{Cu}_{2} \mathrm{O}$, $\mathrm{CuO}, \mathrm{Rh}_{2} \mathrm{O}_{3}, \mathrm{CuRh}_{2} \mathrm{O}_{4}$ and $\mathrm{CuRhO}_{2}$ from elements. 
entropies of formation of the two interoxide compounds from their component binary oxides and from elements and their standard entropies are listed in table 3 . The thermodynamic data for $\mathrm{Rh}\left(\mathrm{S}_{298.15}^{0} / \mathrm{J} \mathrm{mol}^{-1} \mathrm{~K}^{-1}\right.$ $=31.506), \mathrm{O}_{2}\left(\mathrm{~S}_{298.15}^{0} / \mathrm{J} \mathrm{mol}^{-1} \mathrm{~K}^{-1}=205.146\right), \mathrm{Cu}\left(\mathrm{S}_{298.15}^{\mathrm{o}} /\right.$ $\left.\mathrm{J} \mathrm{mol}^{-1} \mathrm{~K}^{-1}=33.162\right)$ and, $\mathrm{Cu}_{2} \mathrm{O}\left(\mathrm{S}_{298 \cdot 15}^{0} / \mathrm{J} \mathrm{mol}^{-1} \mathrm{~K}^{-1}=\right.$ 92.362; $\left.\Delta \mathrm{H}_{298.15}^{\circ} / \mathrm{kJ} \mathrm{mol}^{-1}=-170.711\right)$ and $\mathrm{CuO}\left(\mathrm{S}_{298.15}^{\circ} /\right.$ $\mathrm{J} \mathrm{mol}^{-1} \mathrm{~K}^{-1}=42.589 ; \Delta \mathrm{H}_{298.15}^{\mathrm{o}} / \mathrm{kJ} \mathrm{mol}^{-1}=-156.059$ ) from Knacke et al (1991), and for $\mathrm{Rh}_{2} \mathrm{O}_{3}\left(\mathrm{~S}_{298.15}^{\circ} / \mathrm{J} \mathrm{mol}^{-1} \mathrm{~K}^{-1}\right.$ $=75.69 ; \Delta H_{298.15}^{0} / \mathrm{kJ} \mathrm{mol}^{-1}=-405.53$ ) from a recent

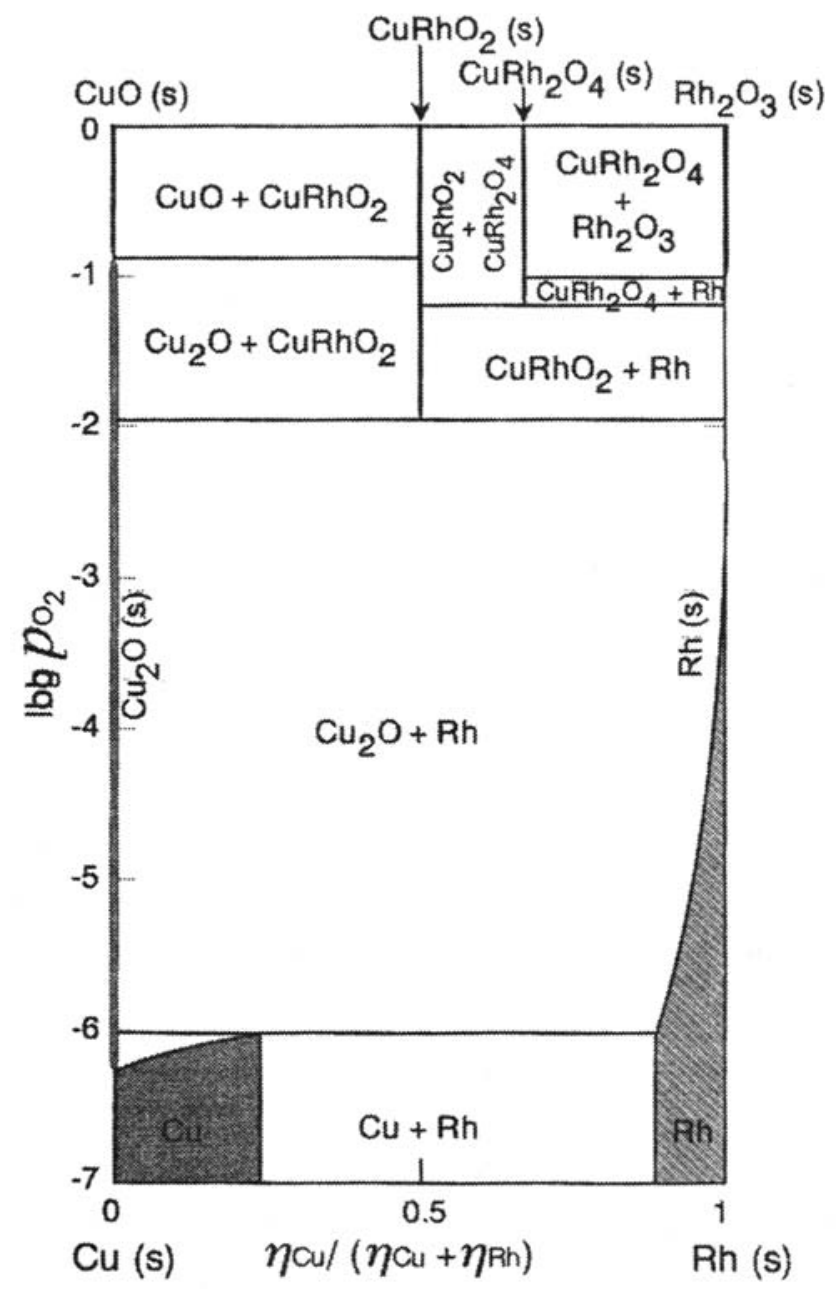

Figure 6. Oxygen potential diagram for the system $\mathrm{Cu}-\mathrm{Rh}-\mathrm{O}$ at $1273 \mathrm{~K}$. analysis by the authors (Jacob et al 1999) are used in the evaluation.

\subsection{Chemical potential diagrams}

The oxygen potential diagram for the system $\mathrm{Cu}-\mathrm{Rh}-\mathrm{O}$ at $1273 \mathrm{~K}$, computed from the results of this study is shown in figure 6. The composition variable is cationic fraction, $\eta_{\mathrm{Rh}} /\left(\eta_{\mathrm{Cu}}+\eta_{\mathrm{Rh}}\right)$, where $\eta_{\mathrm{i}}$ represents moles of component $i$. Since oxygen is not included in the composition parameter, information on oxygen nonstoichiometry cannot be displayed on the diagram. Nevertheless, the diagram provides useful information on the oxygen potential range for the stability of the various phases. The diagram is complimentary to the conventional Gibbs triangle representation of phase relations in ternary systems (figure 1), where the composition of each phase can be unambiguously displayed. All the topological rules of construction for conventional temperature-composition

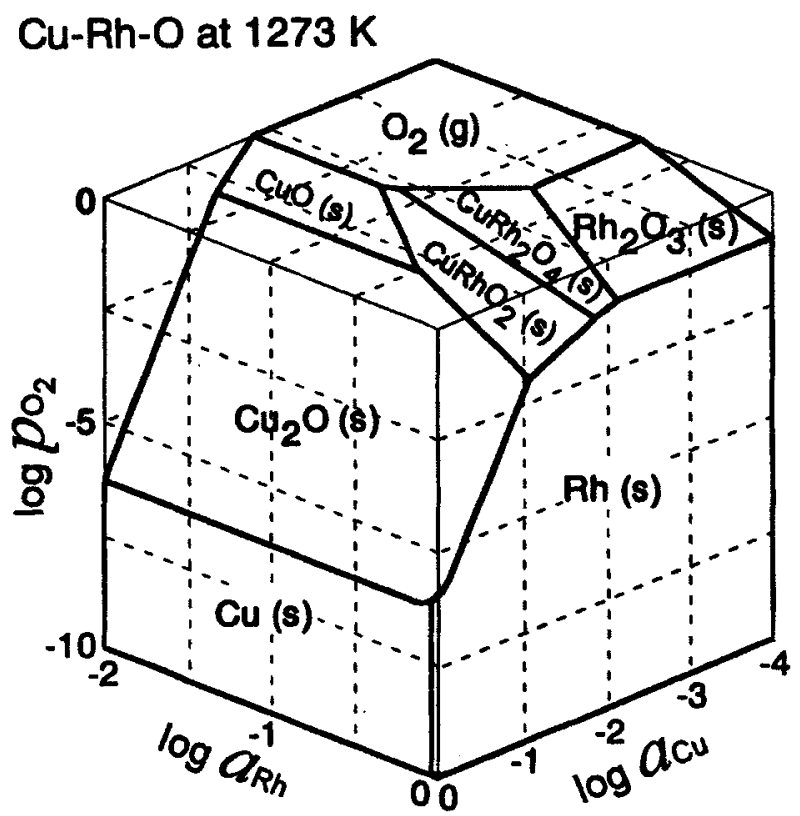

Figure 7. Three-dimensional chemical potential diagram for the system $\mathrm{Cu}-\mathrm{Rh}-\mathrm{O}$ at $1273 \mathrm{~K}$. Planes represent the stability domains of the various condensed phases as a function of the chemical potentials of the three components.

Table 3. Thermodynamic properties of $\mathrm{CuRh}_{2} \mathrm{O}_{4}$ and $\mathrm{CuRhO}_{2}$ at $298 \cdot 15 \mathrm{~K}$.

\begin{tabular}{lccccc}
\hline Compound & $\begin{array}{c}\Delta_{\mathrm{f}(\mathrm{ox})} \mathrm{H}_{298.15}^{\circ} \\
\left(\mathrm{kJ} \mathrm{mol}^{-1}\right)\end{array}$ & $\begin{array}{c}\Delta_{\mathrm{f}} \mathrm{H}_{298.15}^{\circ} \\
\left(\mathrm{kJ} \mathrm{mol}^{-1}\right)\end{array}$ & $\begin{array}{c}\Delta_{\mathrm{f(ox})} \mathrm{S}_{298.15}^{\circ} \\
\left(\mathrm{J} \mathrm{mol}^{-1} \mathrm{~K}^{-1}\right)\end{array}$ & $\begin{array}{c}\Delta_{\mathrm{f}} \mathrm{S}_{298.15}^{\circ} \\
\left(\mathrm{J} \mathrm{mol}^{-1} \mathrm{~K}^{-1}\right)\end{array}$ & $\begin{array}{c}\mathrm{S}_{298.15}^{\circ} \\
\left(\mathrm{J} \mathrm{mol}^{-1} \mathrm{~K}^{-1}\right)\end{array}$ \\
\hline $\mathrm{CuRh}_{2} \mathrm{O}_{4}$ & -23.76 & -585.35 & -1.92 & -390.11 & 116.35 \\
& $( \pm 0.68)$ & $( \pm 0.90)$ & $( \pm 0.61)$ & $( \pm 1.20)$ & $( \pm 0.95)$ \\
$\mathrm{CuRhO}_{2}$ & -18.04 & -306.16 & -0.98 & -186.76 & $\begin{array}{c}83.05 \\
\end{array}$ \\
\hline
\end{tabular}


phase diagrams are applicable to the oxygen potential diagram shown in figure 6 .

When three condensed phases coexist at equilibrium in a ternary system such as $\mathrm{Cu}-\mathrm{Rh}-\mathrm{O}$, the system is bivariant; at a fixed temperature and total pressure, three condensed phases coexist only at a unique partial pressure of oxygen. Therefore, horizontal lines on the diagram represent three-phase equilibria. On reducing the oxygen partial pressure at $1273 \mathrm{~K}$, the binary oxide $\mathrm{CuO}$ dissociates first to $\mathrm{Cu}_{2} \mathrm{O}$ and $\mathrm{O}_{2}$. This is followed by the dissociation of $\mathrm{Rh}_{2} \mathrm{O}_{3}$ to $\mathrm{Rh}$ and $\mathrm{O}_{2}$. Further reduction in oxygen partial pressure causes the dissociation of $\mathrm{CuRh}_{2} \mathrm{O}_{4}$ to $\mathrm{CuRhO}_{2}, \mathrm{Rh}$ and $\mathrm{O}_{2}$. The dissociation of $\mathrm{CuRhO}_{2}$ to $\mathrm{Cu}_{2} \mathrm{O}, \mathrm{Rh}$ and $\mathrm{O}_{2}$ occurs at still lower oxygen partial pressure. The $\mathrm{Cu}-\mathrm{Rh}$ alloys coexist with $\mathrm{Cu}_{2} \mathrm{O}$. Similar oxygen potential diagrams at other temperatures, that may be required to address specific applications, can be readily computed from the thermodynamic data. Phase relations can also be computed as a function of temperature at constant oxygen partial pressure.

It is interesting to view the stability of the various phases as a function of the chemical potentials of the three components. A three-dimensional representation at $1273 \mathrm{~K}$ is displayed in figure 7 . The stability domain of each stoichiometric phase is defined by a plane, because the sum of the chemical potentials of the different components weighted by the appropriate stoichiometric coefficients is equal to the Gibbs energy of formation of the phase. Lines, defined by the intersection of the corresponding planes, represent two-phase fields. Points of intersection of three planes identify three-phase equilibria. It is seen that the stability domains of the ternary oxides are of approximately the same magnitude as those of the binary oxides $\mathrm{CuO}$ and $\mathrm{Rh}_{2} \mathrm{O}_{3}$.

\section{Conclusions}

Isothermal section of the phase diagram of the system $\mathrm{Cu}-\mathrm{Rh}-\mathrm{O}$ at $1273 \mathrm{~K}$ has been established by phase analysis of samples quenched after equilibration at high temperature. Two ternary oxides, $\mathrm{CuRhO}_{2}$ and $\mathrm{CuRh}_{2} \mathrm{O}_{4}$ were stable. The compound $\mathrm{CuRhO}_{2}$ containing monovalent copper was found stable in pure oxygen. Based on the phase diagram, two solid state cells were designed to measure the chemical potential of oxygen corresponding to two phase-fields in the ternary, each involving three condensed phases. The measurements were conducted from 900 to $1300 \mathrm{~K}$ against the primary reference standard for oxygen. The Gibbs energy changes corresponding to the following reactions were directly measured:

$$
\begin{aligned}
& \mathrm{Cu}_{2} \mathrm{O}+2 \mathrm{Rh}+\frac{3}{2} \mathrm{O}_{2} \rightarrow 2 \mathrm{CuRhO}_{2}, \\
& \Delta_{\mathrm{r}} G^{\circ} / \mathrm{J} \mathrm{mol}{ }^{-1}=-432,440+283.95 \mathrm{~T} / \mathrm{K} \quad( \pm 145),
\end{aligned}
$$

$$
\begin{aligned}
& \mathrm{CuRhO}_{2}+\mathrm{Rh}+\mathrm{O}_{2} \rightarrow \mathrm{CuRh}_{2} \mathrm{O}_{4}, \\
& \Delta_{\mathrm{r}} G^{\circ} / \mathrm{J} \mathrm{mol}{ }^{-1}=-269,130+188.90 \mathrm{~T} / \mathrm{K} \quad( \pm 85) .
\end{aligned}
$$

From this information, thermodynamic properties of $\mathrm{CuRhO}_{2}$ and $\mathrm{CuRh}_{2} \mathrm{O}_{4}$ were derived. Contrary to the conclusion of Kahan et al (1987), $\mathrm{Cu}_{2} \mathrm{Rh}_{2} \mathrm{O}_{5}$ was found to be unstable. Chemical potential diagrams including a three-dimensional representation for the system $\mathrm{Cu}-\mathrm{Rh}-\mathrm{O}$ at $1273 \mathrm{~K}$ were developed based on the thermodynamic data obtained in this study and auxiliary information from the literature.

\section{References}

Bertaut F, Forrat F and Dulac J 1959 Compt. Rend. Acad. Sci. 249726

Blasse G 1963 Philips Res. Rep. 18383

Charette G G and Flengas S N 1968 J. Electrochem. Soc. 115 796

Jacob K T and Jeffes J H E 1971 Trans. Inst. Min. Metall. Sec. $C \mathbf{8 0} \mathrm{C} 32$

Jacob K T and Alcock C B 1975 J. Am. Ceram. Soc. 58192

Jacob K T and Alcock C B 1976 Rev. Int. Hautes. Temp. Refract. 1337

Jacob K T and Mathews T 1991 J. Mater. Chem. 1545

Jacob K T and Mathews T 1992 J. Am. Ceram. Soc. 753225

Jacob K T and Sriram M V 1994 Metall. Mater. Trans. A25 1347

Jacob K T, Fitzner K and Alcock C B 1977 Metall. Trans. $B 8$ 451

Jacob K T, Kale G M and Iyengar G N K 1986 J. Mater. Sci. 21 2753

Jacob K T, Kale G M and Iyengar G N K 1989 Metall. Trans. B20 679

Jacob K T, Mathews T and Hajra J P 1992a Mater. Sci. Engg. B15 63

Jacob K T, Kale G M and Waseda Y 1992b Thermochim. Acta 208341

Jacob K T, Mathews T and Hajra J P 1993a Metall. Trans. A24 1655

Jacob K T, Mathews T and Hajra J P 1993b High Temp. Mater. Process. 12251

Jacob K T, Uda T, Okabe T H and Waseda Y 1999 High Temp. Mater. Process. 18 (in press)

Kahan B G, Lazarev W B and Shapligin I S 1987 Russ. J. Inorg. Chem. 32129

Kale G M and Jacob K T 1989 Chem. Mater. 1515

Kale G M and Jacob K T 1992 Metall. Trans. B23 57

Knacke O, Kubaschewski O and Hesselmann K 1991 Thermochemical properties of inorganic substances (Berlin: Springer-Verlag) 2nd ed., Vols I and II

Massalski T B, Subramanian P R, Okamoto H and Kacprzak L (eds) 1990 Binary alloy phase diagrams (Materials Park, Ohio, USA: ASM International) 2nd edn, Vol. 2, p. 1466

Mathews T and Jacob K T 1993a J. Mater. Res. 83015

Mathews T and Jacob K T 1993b J. Mater. Chem. 31025

Mathews T and Jacob K T 1994 J. Am. Ceram. Soc. 77133

Mathews T, Hajra J P and Jacob K T 1993 Chem. Mater. 51669 
Neininger, Schulz and Eysel W 1990 Joint Committee on Powder Diffraction Standards (JCPDS) Card No. 41-0400, Newtown Square, Pennsylvania, USA

Pratt J N 1990 Metall. Trans. A21 1223

Priya S and Jacob K T 1999 J. Phase Equilibria 20 (in press)
Schmahl N G and Minzl E 1965 Zeit. Phys. Chem. (Neue Folge) 47358

Schulz and Eysel W 1990 Joint Committee on Powder Diffraction Standards (JCPDS) Card No. 41-0402, Newtown Square, Pennsylvania, USA 